\author{
MICHAE KOPCZYŃSKI \\ Instytut Historyczny Uniwersytetu Warszawskiego \\ ŁUKASZ SOBECHOWICZ \\ Instytut Historyczny Uniwersytetu Warszawskiego
}

\title{
CIAŁO LUDZKIE I MIASTO: POBOROWI W GUBERNI WARSZAWSKIEJ W ROKU 1913*
}

\begin{abstract}
Abstrakt: Wysokość i wskaźnik masy ciała są miarami antropologicznymi coraz częściej wykorzystywanymi w dociekaniach nad standardem życia populacji historycznych. Przedmiotem artykułu jest ocena, $w$ jaki sposób w miarach tych odzwierciedlają się różnice wyznaniowe (chrześcijanie-Żydzi) oraz społeczno-ekonomiczne (miejsca zamieszkania, zawód, alfabetyzacja) dzielące mieszkańców Królestwa Polskiego na progu Wielkiej Wojny. Podstawę źródłową stanowi blisko 8 tys. pomiarów dwudziestojednoletnich poborowych z guberni warszawskiej.
\end{abstract}

Słowa kluczowe: ciało ludzkie, standard życia, trend sekularny, rozwarstwienie społeczne, antropometria, Żydzi, Królestwo Polskie.
Abstract: Height and Body Mass Index are anthropological measurements increasingly often used in studies on the standard of living of historical populations. This article conducts an assessment of the way in which those measurements reflect religious (Christians-Jews) and socio-economic (place of residence, profession, literacy) differences dividing the inhabitants of the Kingdom of Poland upon the eve of the Great War. The basic sources are almost 8000 measurements of 21-year old recruits from the gubernia of Warsaw.

Keywords: human body, standard of living, secular trend in human stature, social stratification, anthropometry, Jews, Polish Kingdom.

Truizmem jest stwierdzenie, że rewolucja przemysłowa zmieniła wszystkie aspekty ludzkiego życia. Niewiele bardziej odkrywcza będzie opinia, że towarzyszący industrializacji wzrost poziomu urbanizacji doprowadził

* Autorzy pragną podziękować Alicji Budnik, Grażynie Liczbińskiej oraz Jerzemu Bartkowskiemu i Napoleonowi Wolańskiemu za cenne uwagi. Dyrektorowi Muzeum Historii Polski Robertowi Kostro należą się podziękowania za wsparcie dla naszych badań. 
w ciągu półtora stulecia do przemieszczenia się większości ludności z mniej lub bardziej izolowanych wsi i miasteczek do rozrastających się w niespotykanym dotąd tempie dużych miast ${ }^{1}$. Typowy dla społeczeństw przedprzemysłowych „szklany sufit” urbanizacji, wynoszący według Paula Bairocha od 7 do 15\% populacji, pękł w XIX stuleciu we wszystkich niemal krajach Starego Kontynentu ${ }^{2}$. Stało się to tyleż za sprawą lokalizacji przemysłu w pobliżu złóż surowców energetycznych pochodzenia mineralnego, co i dzięki upowszechnieniu kolei, która poszerzając zaplecze aprowizacyjne wielkich miast, pozwoliła im oderwać się od wybrzeży i śródlądowych szlaków wodnych ${ }^{3}$.

Spór o to, czy masowa migracja do miast była efektem poszukiwania lepszych warunków życia, czy też tragiczną konsekwencją niekorzystnych dla uboższych warstw ludności wsi przemian stosunków agrarnych, trwa od samego początku opisywanego zjawiska. Wedle klasycznej wizji Karola Marksa i Fryderyka Engelsa „Burżuazja podporządkowała wieś panowaniu miasta. Stworzyła olbrzymie miasta, zwiększyła w wysokim stopniu liczbę ludności miejskiej w porównaniu z wiejską i wyrwała w ten sposób znaczną część ludności z idiotyzmu życia wiejskiego"4. Wyrwanie się z „idiotyzmu życia wiejskiego" miało swą cenę w postaci dramatycznego pogorszenia warunków życia i pracy. Historycy-rewizjoniści zauważają, że przejście do miast, choć wiążące się z ryzykiem i pogorszeniem stopy życiowej, oznaczało migrację do strefy wyższych dochodów, która

${ }^{1}$ Jako pierwsza doświadczyła tego procesu Wielka Brytania, gdzie w latach 18211831 średnie tempo przyrostu ludności miast wyniosło 2,5\% rocznie, a w latach 1830$1850-3,4 \%$. Szybsze tempo odnotowano w XX w. w krajach Trzeciego Świata - w dekadzie 1960-1970 przyrost urbanizacji (bez Chin) wyniósł 4,2\%, J.G. Williamson, Copying with City Growth During the British Industrial Revolution, Cambridge 1990, s. 3.

${ }_{2}$ P. Bairoch, De Jericho à Mexico: Villes et économie dans l'histoire, Paris 1985; P. Bairoch, G. Goertz, Factors of Urbanization in the Nineteenth Century Developed Countries: A Descriptive and Economietric Analysis, „Urban Studies” 23, 1986, s. 285-305; Paul Bairoch za kryterium miejskości uznaje 5 tys. mieszkańców, obecnie częściej używa się progu 10 tys. mieszkańców. Posługując się tym ostatnim, obliczono, że w 1910 r. zabór pruski miał $34,7 \%$ ludności w miastach, Królestwo Polskie 22,9\%, a Galicja 19,8\%. C. Kuklo, J. Łukasiewicz, C. Leszczyńska, Historia Polski w liczbach. Polska w Europie, Warszawa 2014, s. 57.

3 O znaczeniu mineralnych źródeł energii dla lokalizacji miast i migracji ludności: E.A. Wrigley, Energy and the English Industrial Revolution, Cambridge 2010; idem, Industrial Growth and Population Change. A Regional Study of the Coalfield Areas of North-West Europe in the Later Nineteenth Century, Cambridge 1961. W równaniu regresyjnym skonstruowanym przez P. Bairocha i Gary'ego Goertza (op. cit., s. 295-297) stopień rozwoju sieci kolejowej nie wpływa na urbanizację, ale autorzy przyznają, że wynika to ze sposobu budowy tej zmiennej oraz z autokorelacji pomiędzy rozwojem sieci kolejowej a produktem krajowym brutto (PKB) na głowę i poziomem industrializacji.

${ }^{4}$ K. Marks, F. Engels, Manifest komunistyczny, Warszawa 2007, s. 5. 
była jednocześnie strefą większego rozwarstwienia ${ }^{5}$. W dyskusji nad standardem życia w okresie wczesnej industrializacji biorą udział również demografowie. Przytaczane przez nich liczby jednoznacznie wskazują na dramatyczne pogorszenie się - i tak niełatwych - warunków życia panujących w miastach, co manifestowało się wyższą śmiertelnością niż na terenach niezurbanizowanych ${ }^{6}$. W angielskojęzycznej historiografii zjawisko to zwykło się określać terminem „urban penalty”. Samo to sformułowanie sugeruje, że mamy do czynienia z pewnego rodzaju wymianą jakości życia mierzonej w kategoriach demograficznych i antropologicznych w zamian za poprawę standardu ekonomicznego liczonego w pieniądzu.

W końcu lat dziewięćdziesiątych XX w. Robert W. Fogel sformułował hipotezę o zachodzącej w ostatnich 300 latach ewolucji techno-fizjologicznej ${ }^{7}$. W odróżnieniu od ewolucji genetycznej dokonującej się na drodze trwającego wiele tysięcy lat doboru naturalnego ewolucja techno-fizjologiczna pociąga za sobą jedynie zmiany fenotypowe i trwa - jak dotąd - znacznie krócej. Jej istotą jest zmiana fizyczności człowieka (wzrostu, wagi, wymiarów ciała) oraz reżimu demograficznego, przejście od systemu o wysokiej śmiertelności z krótkim trwaniem życia do reżimu opartego na niskiej śmiertelności i płodności oraz wydłużonym trwaniu życia. Zmiany te zaszły szybko, były pochodną rosnącego panowania człowieka nad otoczeniem dzięki postępowi techniki i nauki, a ich rozprzestrzenienie następowało przez dyfuzję wiedzy, a nie zmiany puli genetycznej. Śledząc przebieg tego procesu, wyróżnić można dwa

${ }^{5}$ S. Kuznets, Economic Growth and Income Inequality, „American Economic Review” 45, 1955, 1, s. 1-28, R.M. Hartwell, S.L. Engerman, Models of Immiseration: the Theoretical Basis of Pessimism, w: The Standard of Living in Britain in the Industrial Revolution, red. A.J. Taylor, London 1975, s. 189-213; J.G. Williamson, Did British Capitalism Breed Inequality?, Boston 1985; szerzej na temat dyskusji o standardzie życia i rewolucji przemysłowej, M. Kopczyński, Standard życia i ,jakość życia" robotników angielskich w epoce rewolucji przemysłowej, w: Gospodarka, ludzie, władza. Studia historyczne ofiarowane prof. Juliuszowi Łukasiewiczowi w 75. rocznicę urodzin, red. M. Kopczyński, A. Mączak, Warszawa 1998, s. 171-204.

${ }^{6}$ Zob. np. P.F. Huck, „Infant Mortality and the Standard of Living during the British Industrial Revolution", Evanston 1992 (praca doktorska), a dla Wielkopolski połowy XIX stulecia G. Liczbińska, Umieralność i jej uwarunkowania wśród katolickiej i ewangelickiej ludności historycznego Poznania, Poznań 2009, eadem, Diseases, Health Status, and Mortality in Urban and Rural Environments: The Case of Catholics and Lutherans in $19^{\text {th }}$-century Greater Poland, „Anthropological Review” 73, 2009, s. 21-36.

7 R.W. Fogel, D.L. Costa, A Theory of Technophysioevolution, With Some Implications for Forecasting Population, Health Care Costs, and Pension Costs, „Demography” 34, 1977, s. 4966; R.W. Fogel, The Escape from Hunger and Premature Death, 1700-2100. Europe, America, and the Third World, Cambridge 2004; R. Floud i in., The Changing Body: Health, Nutrition, and Human Development in the Western World since 1700, New York 2011. 
główne etapy: pierwszy spowodowany wzrostem produktywności rolnictwa i drugi - szczególnie ważny dla ludności miast - warunkowany postępem inżynierii miejskiej, przede wszystkim wodociągów i kanalizacji spławnej. Zanim jednak standard i jakość życia podniosły się w sposób decydujący, upłynęło co najmniej kilkadziesiąt lat.

Przedmiotem analizy jest różnica w standardzie życia ludności miast i wsi Królestwa Polskiego widziana przez pryzmat antropometrii. Za podstawę rozważań posłużą dane o wysokości i masie ciała poborowych z wybranych powiatów guberni warszawskiej, którzy stanęli przed komisjami wojskowymi w latach 1913 i 1914 (urodzeni w latach 1892 i 1893). Celem badania jest próba odpowiedzi na trzy pytania. Czy mierzony miarami antropologicznymi standard życia mieszkańców prowincji był lepszy niż w wielkim mieście? Czy miejsce zamieszkania wpływało silniej na charakterystykę fizyczną niż czynniki etniczno-religijne (przekrój Żydzi-chrześcijanie) oraz ekonomiczne (zawody wykonywane przez poborowych)? I wreszcie, jak miała się sytuacja w Królestwie Polskim do realiów ówczesnej Wielkopolski. Choć badanie ma charakter wycinkowy, to powinno dostarczyć wskazówek do choćby hipotetycznej odpowiedzi na tak sformułowane pytania.

\section{Narzędzia badawcze}

Wysokość i względna masa ciała (ang. body mass index - BMI) należą do wskaźników antropometrycznych stworzonych na użytek antropologii fizycznej i medycyny. W ostatnich trzydziestu latach stały się one narzędziami w dociekaniach historycznych na temat struktury społecznej i standardu życia w przeszłości ${ }^{8}$. Wysokość ciała na poziomie jednostkowym warunkowana jest przez wyposażenie genetyczne, które zostaje w pełni wykorzystane $\mathrm{w}$ optymalnych warunkach środowiskowych $\mathrm{w}$ okresie wzrastania organizmu (pierwsze 17-18 lat życia). Deficyty środowiskowe - niedostateczne wyżywienie, wydatki energetyczne spowodowane nadmiernym wysiłkiem fizycznym lub chorobami - powodują niepełne wykorzystanie potencjału genetycznego ${ }^{9}$. Na poziomie populacji wysokość ciała stanowi więc efekt synergii pomiędzy wyposażeniem genetycznym

${ }^{8}$ Zob. np. R.H. Steckel, Heights and Human Welfare: Recent Developments and New Directions, „Explorations in Economic History” 46, 2009, 1, s. 1-23; K. Inwood, E. Roberts, Longitudinal Studies of Human Growth and Health: A Review of Recent Historical Research, "Journal of Economic Surveys" 24, 2010, 5, s. 801-840.

9 T. Bielicki i in., Nierówności społeczne w Polsce: antropologiczne badania poborowych w trzydziestoleciu 1965-1995, Wrocław 1997, s. 13. 
i środowiskiem, a jego zróżnicowanie i zmiany obserwowane przez długi czas dostarczają informacji na temat ewolucji dobrostanu społeczeństwa.

Historyczne badania nad zmianami średniej wysokości ciała nie są wyłącznie uzupełnieniem i potwierdzeniem rezultatów uzyskanych za pomocą znanych od dawna klasycznych mierników standardu życia, takich jak dochód krajowy brutto per capita czy indeksy płac realnych. Zdarza się, że wskaźniki antropometryczne i ekonomiczne prowadzą do całkiem odmiennych wniosków. Przykładowo w Stanach Zjednoczonych, począwszy od lat trzydziestych po lata osiemdziesiąte XIX stulecia, pomimo rosnącego dochodu narodowego na głowę mieszkańca wysokość ciała młodych mężczyzn się obniżała. Po części był to efekt złych warunków higienicznych w miastach, ale w jeszcze większym stopniu konsekwencja zmieniających się relacji cen żywności w stosunku do innych towarów, co owocowało zubożeniem diety w białko zwierzęce ${ }^{10}$. Negatywne z punktu widzenia biologicznego konsekwencje industrializacji obserwowano nie tylko w USA ${ }^{11}$.

Badania dotyczące Królestwa Polskiego oparte były na pomiarach wysokości ciała poborowych urodzonych pomiędzy 1846 a $1892 \mathrm{r}^{12}$ Wykazały one istotne podnoszenie się tego parametru, począwszy od generacji urodzonej w połowie lat sześćdziesiątych oraz zahamowanie trendu ku wysokorosłości w generacjach urodzonych na przełomie lat osiemdziesiątych i dziewięćdziesiątych, co przypisano wpływowi kryzysu agrarnego ostatniej ćwierci XIX w. ${ }^{13}$ Badanie ujawniło nie tylko różnicę w wysokości ciała chrześcijan i Żydów, lecz również odrębny przebieg trendu. $\mathrm{O}$ ile w okresie podnoszenia się wysokości ciała trend pozytywny dotyczył obu grup, o tyle w ostatniej dekadzie XIX stulecia stagnacji wysokości ciała chrześcijan towarzyszyło obniżenie się średniej Żydów. Widoczne ono było przede wszystkim w małych miastach, gdyż wysokość ciała Żydów mieszkających w Warszawie podnosiła się w podobny sposób jak w przypadku chrześcijan. Kolejną uderzającą cechą była przewaga wysokości ciała mieszkańców Warszawy nad mieszkańcami wsi i małych

$10 \mathrm{~J}$. Komlos, The Height and Weight of West Point Cadets: Dietary Change in Antebellum America, „The Journal of Economic History” 47, 1987, 4, s. 897-927; idem, A Three-Decade History of the Antebellum Puzzle: Explaining the Shrinking of the U.S. Population at the Onset of Modern Economic Growth, „The Journal of the Historical Society” 12, 2012, 4, s. 395-445.

${ }^{11}$ Zob. np. Height and Welfare during Industrialization, red. R.H. Steckel, R. Floud, New York 1997; J. Komlos, Shrinking in a Growing Economy? The Mystery of Physical Stature during the Industrial Revolution, „The Journal of Economic History” 58, 1998, 3, s. 779-802.

${ }_{12}$ M. Kopczyński, Wielka transformacja. Badania nad uwarstwieniem społecznym i standardem życia w Królestwie Polskim 1866-1913 w świetle pomiarów antropometrycznych poborowych, Warszawa 2006.

13 Ibidem, s. 155-160. 
miast. Nie była ona efektem różnic struktury społeczno-zawodowej, rysowała się bowiem także w grupach porównywalnych pod względem statusu mierzonego wykonywanym zawodem. Zjawisko to różni Królestwo Polskie od realiów amerykańskich i angielskich, gdzie ludność wsi była wyższa niż mieszkańcy miast ${ }^{14}$. Doganianie wielkiego miasta przez wieś w drugiej połowie XIX w. świadczy o relatywnie niskim poziomie życia ludności chłopskiej w okresie przed uwłaszczeniem.

Drugi rodzaj statystyki, rzadziej wykorzystywany w badaniach historycznych, ale za to popularny w odniesieniu do populacji współczesnych, stanowi względna masa ciała (BMI) obliczana jako iloraz masy ciała w kilogramach i kwadratu wysokości ciała wyrażonej w metrach. Wskaźnika tego używa się dla oceny stopnia otłuszczenia ciała zarówno w odniesieniu do populacji, jak i do jednostek. Wysokie średnie BMI populacji oznacza podwyższone ryzyko występowania chorób chronicznych, takich jak cukrzyca, choroby krążenia, niektóre typy nowotworów. Swą nadzwyczajną popularność zawdzięcza jednak BMI nie tyle medycynie, ile modzie na odchudzanie, a liczne kalkulatory ułatwiające obliczenie tego wskaźnika znaleźć można w Internecie.

Wbrew pozorom BMI nie jest tak proste w interpretacji, jak mogłoby się wydawać na podstawie popularnych kompendiów, a jego zastosowanie do populacji historycznych nie może polegać na automatycznym przenoszeniu interpretacji współczesnych w przeszłość. O ile dziś wysokie BMI kojarzy się $\mathrm{z}$ otłuszczeniem ciała, o tyle $\mathrm{w}$ dawnych populacjach ukazuje ono raczej różnicę w masie mięśniowej. Jak wskazują Barry Bogin i Ines Varela-Silva, BMI nie może być traktowane jako miernik otłuszczenia w badaniach nad populacjami dawniejszymi niż rok 1980, który uznawany jest w za początek światowej epidemii otyłości ${ }^{15}$. Nawet

${ }^{14}$ Przegląd literatury w tej kwestii dają J. Treme, L.A. Craig, Urbanization, Health and Human Stature, „Bulletin for Economic Research” 65, 2013, 1, s. 130-141. Na kontynencie europejskim zaobserwowano wyjątki od tej reguły zarówno w pierwszej, jak i drugiej połowie XIX stulecia, zob. R. Floud i in., The Changing Body, s. 230-232; T. Schoch, K. Staub, Ch. Pfister, Social Inequality and the Biological Standard of Living: An Anthropometric Analysis of Swiss Conscription Data, 1875-1950, „Economics and Human Biology” 10, 2012, 2, s. 154-173; J. Reis, „Urban Premium” or „Urban Penalty”? The Case of Lisbon, 18401912, „Historia Agraria” 47, 2009, s. 69-94.

${ }_{15}$ B. Bogin, I. Varela-Silva, The Body Mass Index: the Good, the Bad, and the Horrid, „Bulletin der Schweizerischen Gesellschaft für Anthropologie" 18, 2012, 2, s. 5-11. Znaczenie lat osiemdziesiątych XIX w. jako dekady przełomowej podważają John Komlos, Marek Brabec (The Trend of BMI Values of US Adults by Deciles, Birth Cohorts 1882-1986 Stratified by Gender and Ethnicity, „Economics and Human Biology” 9, 2011, 3, s. 247-249), wskazując, że przyrosty wartości BMI są skorelowane z takimi zmiennymi jak upowszechnienie telewizji i kultury fast foodów, które zarysowały się już 20-30 lat przed 1980 r. 
w populacjach współczesnych wartość BMI bywa myląca. Przykładowo, 24,6\% dorosłych Amerykanów badanych w 1994 r. na użytek National Health and Nutrition Examination Survey zostało błędnie zakwalifikowanych na podstawie BMI jako osoby z nadwagą, choć inne mierniki (obwód w pasie i pomiar fałdów skórno-tłuszczowych) wniosku tego nie potwierdzały ${ }^{16}$. Do podobnej konkluzji skłaniają wyniki pomiarów młodzieży brytyjskiej wedle pochodzenia społecznego. Wśród szesnastolatków wysokość ciała chłopców z rodzin pracowników umysłowych była wyższa niż dzieci z rodzin pracowników fizycznych, tymczasem BMI synów tych ostatnich było większe. W ten sposób odzwierciedliła się różnica w proporcjach między tkanką tłuszczową (lżejszą) i mięśniową (cięższą od tłuszczu) w badanych grupach ${ }^{17}$.

Stosunkowo rzadkie wykorzystywanie BMI w badaniach historycznych wynika przede wszystkim z braku danych źródłowych. $\mathrm{O}$ ile wysokość ciała od dawna uznawano za właściwość ułatwiającą identyfikację jednostek, czy też najbardziej podstawową cechę warunkującą przydatność do służby wojskowej, o tyle masa ciała uchodziła za cechę zbyt labilną, by opierać na niej identyfikację osób ${ }^{18}$. Na przeszkodzie zgromadzeniu większych zasobów danych legła też znacznie późniejsza niż w przypadku urządzeń do pomiaru wysokości ciała ewolucja urządzeń do ważenia ludzi ${ }^{19}$. W obiegu naukowym znaleźć więc można niezbyt wiele zespołów danych. Znajdują się wśród nich pomiary kadetów z amerykańskich szkół wojskowych, weteranów wojny secesyjnej mierzonych i ważonych pod koniec XIX stulecia, więźniów, uczniów austriackich szkół wojskowych i studentów różnych szkół ${ }^{20}$.

${ }^{16}$ B. Bogin, I. Varela-Silva, op. cit., s. 6.

${ }_{17}$ G.W. Lasker, C.G.N. Mascie-Taylor, Effects of Social Class Differences and Social Mobility on Growth in Height, Weight and Body Mass Index in a British Cohort, "Annals of Human Biology" 16, 1989, 1, s. 1-8.

${ }_{18}$ G. Vigarello, Historia otyłości od średniowiecza do XX wieku, Warszawa 2012 (oryg. franc. 2010), s. 234; o zastosowaniu antropometrii do identyfikacji przestępców zob. J. Thorwald, Stulecie detektywów, Warszawa 1992 (oryg. niem. 1965), s. 23-99.

${ }_{19}$ G. Vigarello, op. cit., s. 290-292; J.M. Tanner, A History of the Study of Human Growth, Cambridge 1981, s. 66-68.

${ }_{20}$ P.A. Coclanis, J. Komlos, Nutrition and Economic Development in Post-Reconstruction South Carolina: An Anthropometric Approach, „Social Science History” 19, 1995, 1, s. 91-115; J. Komlos, The Height Increment and BMI Values of Elite Central European Children and Youth in the Second Half of the $19^{\text {th }}$ Century, "Annals of Human Biology” 33, 2006, 3, s. 309-318; S.A. Carson, Racial Differences in Body Mass Indices of Men Imprisoned in the $19^{\text {th }}$ Century Texas, „Economics and Human Biology” 7, 2009, 1, s. 121-127; idem, The Body Mass Index of Blacks and Whites in the United States during the Nineteenth Century, "The Journal of Interdisciplinary History" 42, 2012, 3, s. 371-391; C. Linares, D. Su, Body Mass Index 
Z ziem polskich dysponujemy sięgającym lat sześćdziesiątych XIX w. ciągiem informacji dotyczących poborowych z zaboru pruskiego. Ciekawą cechą zaobserwowaną $\mathrm{w}$ tych danych jest rozbieżność pomiędzy wysokością ciała a BMI zależną od charakterystyki społecznej badanych. Tak więc synowie inteligencji, choć najwyżsi, mieli jednocześnie mniejsze BMI niż poborowi wywodzący się z rodzin chłopskich. Rozbieżność tę autorzy tłumaczą różnicą jakościową w diecie pomiędzy wsią a miastem. Drugim czynnikiem warunkującym tę różnicę było, wedle cytowanych autorów, większe obciążenie młodzieży wiejskiej pracą fizyczną we wczesnym okresie ontogenezy, co owocowało przyrostem masy mięśniowej. Warto też zwrócić uwagę na brak różnicy w BMI pomiędzy poborowymi chrześcijanami i starozakonnymi ${ }^{21}$.

\section{Źródło i metoda}

Rosyjskie władze wojskowe aż do 1912 r. oceniały przydatność poborowych do służby wojskowej, opierając się na wywiadzie lekarskim oraz pomiarze wysokości ciała i obwodu klatki piersiowej. Ten ostatni odniesiony do wysokości ciała służyć miał ocenie, czy poborowy nie wykazuje wczesnych objawów gruźlicy. Początkowo przyjęto założenie, że obwód klatki piersiowej winien być równy przynajmniej połowie wysokości ciała. Kiedy okazało się, że reguła ta powoduje odraczanie wyższych poborowych, zdecydowano się obniżyć normę o $2,2 \mathrm{~cm}^{22}$. Choć ważenie poborowych zalecono $\mathrm{w}$ instrukcji dla lekarzy pracujących w komisjach poborowych w 1912 r., to jednak rejestry poborowe (prizywnyje spiski) z listopadowego poboru nie zawierają jeszcze informacji o masie ciała. Dopiero od 1913 r. informacja ta stała się standardem. Do masy ciała nie przywiązywano jednak tak dużej wagi, jak do szerokości klatki piersiowej. W instrukcji podano jedynie orientacyjne normy: osobnik o wzroście $155 \mathrm{~cm}$ winien ważyć $51-58 \mathrm{~kg}$, o wzroście $160 \mathrm{~cm}-54-61 \mathrm{~kg}$,

and Health Among Union Army Veterans: 1891-1905, „Economics and Human Biology” 3, 2005, 3, s. 367-387; S. Horrell, D. Meredith, D. Oxley, Measuring Misery: Body Mass, Ageing and Gender Inequality in Victorian London, „Explorations in Economic History” 46, 2009, 1, s. 93-119; J. Komlos, M. Brabec, op. cit., s. 234-250.

${ }^{21}$ O. Nowak, Wysokość ciała i masa ciała młodych mężczyzn w okresie przemian historycznych i społeczno-gospodarczych drugiej połowy XIX i na poczatku XX wieku na ziemiach polskich, Poznań 2011; G. Liczbińska i in., Body Mass Index Values of Conscripts in the Polish Lands under Prussian Rule in the Late 19th and Early 20th Centuries, „Economics and Human Biology" 2016, 21, s. 75-83.

${ }_{22}$ M. Kopczyński, Wielka transformacja, s. 51-52. 
$164,5 \mathrm{~cm}-57-64 \mathrm{~kg}$ aż po $182 \mathrm{~cm}-70-77 \mathrm{~kg}$. Wyliczony na tej podstawie wskaźnik BMI wynosi od 21,1 do $23,8^{23}$.

Poniższą analizę oparto na pomiarach 7765 poborowych stających do poboru w $1913 \mathrm{r}$. z Warszawy (2606 osób) oraz położonych w guberni warszawskiej powiatów grójeckiego (1483 osoby), nowomińskiego (rok 1914, 948 osób), pułtuskiego (978 poborowych), płońskiego (923 osoby) i radzymińskiego (827 obserwacji) ${ }^{24}$. Poza pomiarami źródło odnotowuje wyznanie, zawód wykonywany przez poborowego oraz miejsce zamieszkania. Na potrzeby analizy miejsce zamieszkania podzielono na trzy kategorie: wieś, miasto i Warszawa ${ }^{25}$. W przypadku zawodu zastosowano podział na rolników, handlowców, rzemieślników, pracowników wykwalifikowanych, robotników dniówkowych oraz osoby bez określonego zawodu. Robotników dniówkowych określano w źródle najczęściej terminem czernoraboczij i byli to w większości robotnicy rolni. Dodatkową informacją pozwalającą różnicować wyodrębnione podgrupy jest zapis dotyczący umiejętności czytania i pisania, choć trudno określić, czy chodziło o znajomość rosyjskiego, czy też polskiego lub jidysz.

Charakterystykę poborowych pod kątem wyznania i miejsca zamieszkania oraz wykonywanego zawodu i miejsca zamieszkania obrazują tabele 1-2.

Jak należało oczekiwać, chrześcijanie wywodzili się przede wszystkim ze wsi ( $3 / 4$ ogółu w próbie). W miastach i osadach (posad) przeważali Żydzi, co pozostaje w zgodzie ze statystyką ludności. Inaczej było w Warszawie, gdzie wśród ogółu ludności większość stanowili chrześcijanie, podczas gdy wśród przebadanych poborowych liczba Żydów przewyższała liczbę chrześcijan ${ }^{26}$. Przyczynić się do tego mogły dwie okoliczności. Z jednej strony był to zapewne efekt różnicy w strukturze według wieku między chrześcijanami i Żydami, z drugiej zaś skutek polityki rosyjskich władz

${ }^{23}$ Ibidem, Instrukcję z 1912 r. podaje Pavel S. Cypkin, Ustav o voinskoj povinnosti s raz"âsneniâmi Pravitel'stvuûsego Senata i Ministerstv Voennego, Morskogo i Vnutrennih Del, wyd. 2, S. Peterburg 1915, s. 131.

${ }^{24}$ Archiwum Państwowe w Warszawie (APW), oddział w Milanówku: Warszawski miejski urząd ds. powinności wojskowej 1103; APW, oddział w Grodzisku Mazowieckim: urząd powiatowy grójecki ds. powinności wojskowej 1456, urząd powiatowy nowo-miński ds. powinności wojskowej 576, urząd powiatowy radzymiński ds. powinności wojskowej 603, APW, oddział w Mławie: urząd powiatowy płoński ds. powinności wojskowej 1179, APW, oddział w Pułtusku: urząd powiatowy pułtuski ds. powinności wojskowej 23.

${ }^{25}$ W kategorii miasta znalazły się: Góra Kalwaria, Grójec, Kałuszyn, Nasielsk, Mińsk Mazowiecki (Nowomińsk), Płońsk, Pułtusk, Radzymin, Warka, Zakroczym oraz osady (posad): Czersk, Jadów, Kołbiel, Mogielnica, Serock i Wyszków.

${ }^{26}$ W 1897 r. Żydzi stanowili 33, a w 1913 r. - 38\% ludności Warszawy, podczas gdy w spisach poborowych stanowili oni ponad 40\%, a po roku 1905 ponad 50\%. 
Tabela 1. Charakterystyka poborowych wedle pochodzenia etnicznego i miejsca zamieszkania. Gubernia warszawska 1913 r.

\begin{tabular}{|l|c|c|c|c|c|c|}
\hline $\begin{array}{c}\text { Wyznanie } \\
\text { zamiejsce }\end{array}$ & Chrześcijanie & $\begin{array}{c}\text { Chrześcijanie } \\
\text { (\%) }\end{array}$ & Żydzi & $\begin{array}{c}\text { Żydzi } \\
\text { (\%) }\end{array}$ & Razem & $\begin{array}{c}\text { Odsetek } \\
\text { osób } \\
\text { w próbie }\end{array}$ \\
\hline Wieś & 3982 & 74,2 & 211 & 8,8 & 4193 & 54,0 \\
\hline Miasta & 275 & 5,2 & 691 & 28,8 & 966 & 12,4 \\
\hline Warszawa & 1107 & 20,6 & 1499 & 62,4 & 2606 & 33,6 \\
\hline Razem & 5364 & 100,0 & 2401 & 100,0 & 7765 & 100,0 \\
\hline
\end{tabular}

Źródło: zob. przyp. 24.

Tabela 2. Poborowi wedle miejsca zamieszkania i zawodu. Gubernia warszawska $1913 \mathrm{r}$.

\begin{tabular}{|c|c|c|c|c|c|c|c|c|}
\hline Wyznanie & & Chrześc & ijanie & & & Żyd & & \\
\hline $\begin{array}{c}\text { Zawód/miejsce } \\
\text { zamieszkania }\end{array}$ & wieś & miasta & Warszawa & Razem & wieś & miasta & Warszawa & Razem \\
\hline Rolnik & 1591 & 29 & 16 & 1636 & 1 & 5 & - & 6 \\
\hline Robotnik & 1314 & 58 & 116 & 1488 & 33 & 93 & 89 & 215 \\
\hline Handel & 18 & 2 & 68 & 88 & 74 & 210 & 496 & 780 \\
\hline Rzemiosło & 609 & 107 & 545 & 1261 & 54 & 194 & 576 & 824 \\
\hline Wykwalifikowany & 63 & 30 & 222 & 315 & 2 & 14 & 238 & 254 \\
\hline Nieokreślony & 387 & 49 & 140 & 576 & 47 & 175 & 100 & 322 \\
\hline Razem & 3982 & 275 & 1107 & 5364 & 211 & 691 & 1499 & 2401 \\
\hline
\end{tabular}

Źródło: zob. przyp. 24.

wojskowych dążących do wcielania w szeregi armii przedstawicieli grup etniczno-wyznaniowych w proporcji takiej, w jakiej występowali w populacji. Ponieważ znaczny odsetek Żydów ukrywał się przed poborem, a nie mniejsza liczba okazywała się niezdolna do służby z powodów zdrowotnych, wyznaczony odgórnie limit Żydów w kontyngencie poborowych nie był wypełniany. W tej sytuacji władze ograniczyły drastycznie stosowanie wobec Żydów ulg z tytułu sytuacji rodzinnej i nakazały badanie medyczne nawet jedynaków ${ }^{27}$. Wśród chrześcijan jedyni synowie nie byli badani, lecz od razu przenoszeni do rezerwy.

${ }^{27}$ Na temat polityki władz wobec Żydów przy poborze i jej konsekwencji, M. Kopczyński, Pobór do armii rosyjskiej w Warszawie i guberni warszawskiej, 1874-1913, „Rocznik Warszawski" 35, 2007, s. 87-109. 
Choć badana próba nie ma charakteru reprezentatywnego ani dla Królestwa, ani dla guberni warszawskiej, to jednak z racji swej dużej liczebności pozwala na wyciągnięcie dostatecznie pewnych wniosków w przekroju miasto-wieś i chrześcijanie-Żydzi. W celu uogólnienia konkluzji posłużymy się metodami statystyki matematycznej, przyjmując istotność (p) na poziomie $0,05^{28}$.

\section{Rezultaty}

Przeciętną wysokość i masę ciała wedle miejsca zamieszkania zestawiono w tabeli 3. Kolumny z nagłówkiem SD informują o wartości odchylenia standardowego, miary rozproszenia obserwacji wokół wartości średniej.

Tabela 3. Wysokość i masa ciała wedle pochodzenia etnicznego i miejsca zamieszkania. Gubernia warszawska $1913 \mathrm{r}$.

\begin{tabular}{|c|c|c|c|c|c|c|c|c|c|c|}
\hline \multirow{2}{*}{$\begin{array}{c}\text { Miejsce } \\
\text { zamieszkania }\end{array}$} & \multicolumn{5}{|c|}{ Chrześcijanie } & \multicolumn{5}{|c|}{ Żydzi } \\
\hline & $\begin{array}{c}\text { wysokość } \\
\text { w cm }\end{array}$ & SD & $\begin{array}{l}\text { masa } \\
\text { w kg }\end{array}$ & $\mathrm{SD}$ & $\mathrm{N}$ & $\begin{array}{c}\text { wysokość } \\
\text { w cm }\end{array}$ & SD & $\begin{array}{l}\text { masa } \\
\mathrm{w} \mathrm{kg}\end{array}$ & SD & $\mathrm{N}$ \\
\hline Wieś & 166,1 & 5,66 & 61,3 & 6,35 & 3982 & 162,5 & 5,50 & 55,9 & 7,63 & 211 \\
\hline Miasta & 166,8 & 6,49 & 60,5 & 6,75 & 275 & 161,6 & 5,70 & 54,6 & 6,54 & 691 \\
\hline Warszawa & 167,1 & 6,57 & 58,7 & 6,91 & 1107 & 162,8 & 6,33 & 54,2 & 8,10 & 1499 \\
\hline Ogół & 166,3 & 5,92 & 60,7 & 6,57 & 5364 & 162,4 & 6,10 & 54,4 & 7,66 & 2401 \\
\hline
\end{tabular}

Źródło: zob. przyp. 24.

Zarówno wysokość dwudziestojednoletnich poborowych, jak i ich masa ciała z trudem dają się odnieść do współczesnych siatek centylowych sporządzanych na podstawie pomiarów młodzieży polskiej ${ }^{29}$. Średnia wysokość ciała wynosząca $166 \mathrm{~cm}$ dla chrześcijan plasuje się poniżej 3 centyla siatki współczesnej dla osiemnastolatków, z kolei wartość $162 \mathrm{~cm}$ dla Żydów znajduje się na poziomie 3 centyla dla chłopców piętnastoletnich. Nieco inaczej przedstawiają się dane o masie ciała. Przeciętna masa chrześcijan równa jest wartości 15 centyla na siatce współczesnej chłopców osiemnastoletnich, a masa ciała Żydów odpowiada centylowi 3

${ }^{28}$ Oznacza to, że w 95 na 100 prób wylosowanych z badanej populacji wniosek potwierdziłby się; innymi słowy, prawdopodobieństwo, że wniosek wysnuty na podstawie próby nie potwierdziłby się w odniesieniu do całej populacji, jest mniejsze niż 0,05.

${ }^{29}$ Z. Kułaga i in., Siatki centylowe wysokości, masy ciała i wskaźnika masy ciała dzieci i młodzieży w Polsce - wyniki badania OLAF, „Standardy Medyczne” 7, 2010, s. 690-700. 


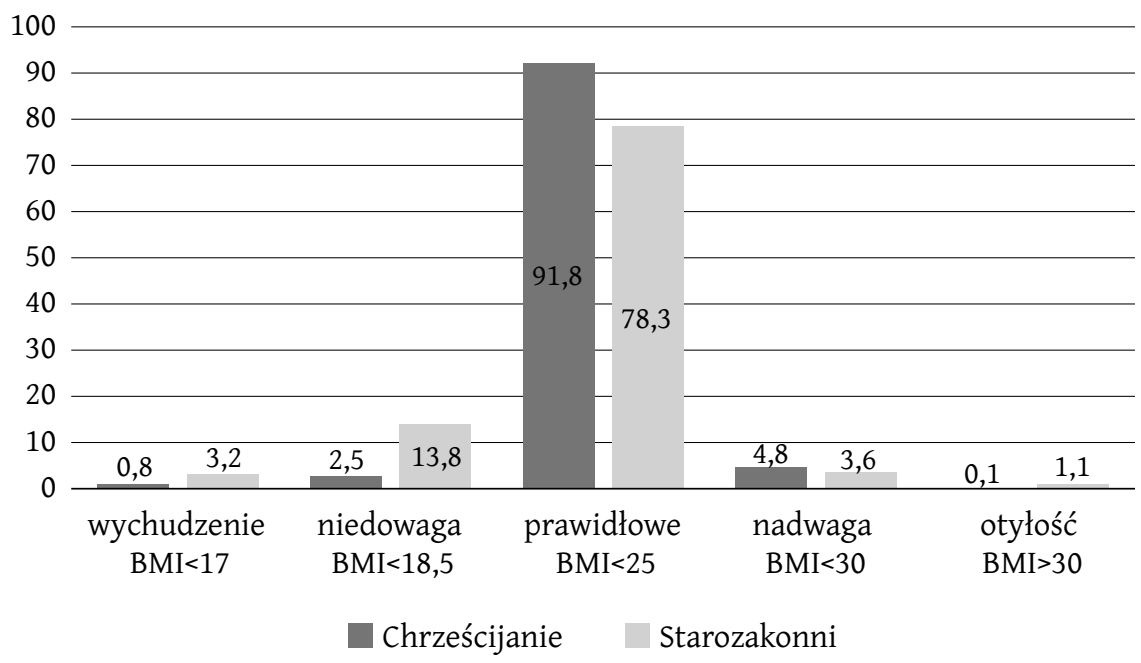

Wykres 1. Indeks masy ciała (BMI) poborowych z guberni warszawskiej w $1913 \mathrm{r}$. według wyznania (w proc.)

Źródło: zob. przyp. 24.

tej samej siatki. Jeszcze bardziej w środku współczesnej stawki znajdują się wartości BMI: dla chrześcijan średnia mieści się w środku dzisiejszego standardu osiemnastolatków, a dla Żydów przekracza centyl 25.

Odmiennie niż w Wielkopolsce przełomu XIX i XX w. zróżnicowanie parametrów między chrześcijanami i Żydami było w Królestwie bardzo znaczne, a statystyczna istotność różnicy nie budzi wątpliwości. Różnica w wysokości ciała wynosząca 3,5-5 cm utrzymywała się we wszystkich wyodrębnionych kategoriach. Największy rozmiar osiągała w małych miastach, w których warunki życia ludności żydowskiej były najtrudniejsze. Również masa ciała wykazywała istotną statystycznie, ponad czterokilogramową różnicę między obiema grupami wyznaniowymi. Cechą rzucającą się w oczy było znacznie większe rozproszenie obserwacji dla poborowych wyznania mojżeszowego.

Rozkład wartości BMI w zbiorowości poborowych wyznania chrześcijańskiego bliski był symetrii. Wynoszący blisko 5 odsetek poborowych z nadwagą i otyłych jest tylko nieznacznie mniejszy niż wśród dziewiętnastoletnich poborowych do Ludowego Wojska Polskiego badanych w roku 1965 (urodzeni w 1946 r.). Współcześnie - rok 2001, dla urodzonych w 1982 r. - odsetek ten sięga 17, co stanowi miarę narastania epidemii otyłości w Polsce drugiej połowy XX w. ${ }^{30}$ Całkiem inaczej przedstawiał się

30 T. Bielicki i in., Transformacja ustrojowa $w$ Polsce $w$ świetle antropologicznych badań 19-letnich poborowych, Wrocław 2003, s. 94-97, tablice 27-30. 
na początku XX stulecia rozkład wartości BMI dla Żydów. Cechowała go zdecydowana asymetria lewostronna z powodu $17 \%$ poborowych z niedowagą lub objawami wychudzenia, które jednak nie miały wpływu na decyzje komisji o przyjęciu do służby lub odroczeniu, choć wartości BMI były niższe od cytowanych wyżej zaleceń. Chęć wypełnienia kontyngentu okazała się zbyt silna. Warto zauważyć, że 3/4 osób z niedowagą mieszkało w Warszawie, stanowiąc równo $20 \%$ Żydów warszawskich.

Z tego, co powiedziano powyżej, wynika, że wysokość ciała i jego względna masa dają przeciwstawne sygnały: mieszkańcy Warszawy byli wyżsi, ale ich BMI niższe. Podobna tendencja zarysowała się w przypadku chrześcijan. W Warszawie na niedowagę cierpiało $8,4 \%$ poborowych, podczas gdy na wsi jedynie niecałe $2 \%$. Idąc tym tropem, przeanalizujemy różnicę w budowie fizycznej grup zdefiniowanych przez miejsce zamieszkania (tabele 4 i 5).

Wartości BMI chrześcijan i Żydów różnią się w całej populacji o 1,3 punktu (por. kolumny zatytułowane BMI), czyli o bez mała jedno odchylenie standardowe, co stanowi różnicę bardzo znaczną. Warto jednak zwrócić uwagę, że w miarę przechodzenia ze wsi do miast i do Warszawy, różnica ta ulega stopniowemu zmniejszeniu, by w Warszawie stopnieć do 0,5 punktu (choć nadal pozostaje statystycznie istotna). 0 ile wysokość ciała chrześcijan różniła się w sposób nieprzypadkowy jedynie w parze wieś-Warszawa, o tyle w przypadku BMI wszystkie różnice miały charakter systematyczny i statystycznie istotny. Oznacza to, że wraz z przejściem ze wsi do miasta poborowi stawali się wyżsi, ale jednocześnie lżejsi. Wśród Żydów tendencja była podobna, z tą różnicą, iż wysokość ciała nielicznej grupy zamieszkującej wsie była bliska wartościom warszawskim. Wynika stąd, że siła oddziaływania miejsca zamieszkania na BMI była większa niż siła czynnika określonego przez pochodzenie etniczne, który w największym stopniu determinował różnicę wysokości ciała (zob. tabela 3).

Jak już wspomniano, poza wyznaniem i miejscem zamieszkania źródło informuje o zawodach wykonywanych przez poborowych oraz o alfabetyzacji. Siłę oddziaływania poszczególnych czynników (pochodzenie etniczne, miejsce zamieszkania, zawód, alfabetyzacja) oddaje model regresyjny przedstawiony w tabeli 6 . Stałe obrazują przeciętną wysokość ciała i BMI zamieszkującego wieś chrześcijanina, analfabety o nieokreślonym zawodzie. Wartości w kolumnie drugiej i trzeciej wskazują, jak zmieniają się te parametry pod wpływem poszczególnych zmiennych. Gwiazdką oznaczono czynniki statystycznie istotne na poziomie 0,05, czyli takie, które można przenieść $\mathrm{z}$ badanej próby na całą populację przy ryzyku popełnienia błędu mniejszym niż $5 \%$. 
Tabela 4. Wysokość ciała wedle miejsca zamieszkania i pochodzenia etnicznego (istotność różnic wg statystyki Tukey’a HSD). Gubernia warszawska 1913 r.

\begin{tabular}{|l|c|c|c|c|c|c|}
\hline & \multicolumn{3}{|c|}{ Chrześcijanie } & \multicolumn{3}{c|}{ Żydzi } \\
\hline $\begin{array}{c}\text { Miejsce } \\
\text { zamieszkania }\end{array}$ & 1 & 2 & 3 & 1 & 2 & 3 \\
\hline Wieś (1) & $\times$ & 0,106 & 0,000 & $\times$ & 0,134 & 0,851 \\
\hline Miasto (2) & 0,106 & $\times$ & 0,695 & 0,134 & $\times$ & 0,000 \\
\hline Warszawa (3) & 0,000 & 0,695 & $\times$ & 0,851 & 0,000 & $\times$ \\
\hline
\end{tabular}

$\mathrm{F}=15,195, \mathrm{p}=0,000 \quad \mathrm{~F}=8,641 \mathrm{p}=0,000$

Wartość w rozkładzie F, która pozwala na obliczenie poziomu istotności (p).

Wartości w poszczególnych polach oznaczają poziomy istotności. Wartości mniejsze niż 0,05 wskazują różnice nie mające charakteru przypadkowego. Wartości p pod tabelą odnoszą się do całej badanej próby.

Źródło: zob. przyp. 24.

Tabela 5. Względna masa ciała (BMI) wedle miejsca zamieszkania i pochodzenia etnicznego (istotność różnic wg statystyki Tukey’a HSD)

\begin{tabular}{|l|c|c|c|c|c|c|c|c|}
\hline & \multicolumn{3}{|c|}{ Chrześcijanie } & \multicolumn{4}{c|}{ Żydzi } & \multicolumn{3}{c|}{} \\
\hline $\begin{array}{c}\text { Miejsce } \\
\text { zamieszkania }\end{array}$ & $\mathbf{1}$ & 2 & 3 & BMI & 1 & 2 & 3 & BMI \\
\hline Wieś (1) & $\times$ & 0,000 & 0,000 & 22,21 & $\times$ & 0,379 & 0,000 & 21,18 \\
\hline Miasto (2) & 0,000 & $\times$ & 0,000 & 21,72 & 0,379 & $\times$ & 0,000 & 20,91 \\
\hline Warszawa (3) & 0,000 & 0,000 & $\times$ & 20,99 & 0,000 & 0,000 & $\times$ & 20,43 \\
\hline Ogółem & $\times$ & $\times$ & $\times$ & 21,93 & $\times$ & $\times$ & $\times$ & 20,63 \\
\hline
\end{tabular}

$\mathrm{F}=185,254 \mathrm{p}=0,000 \quad \mathrm{~F}=13,806 \mathrm{p}=0,000$

Wartości w poszczególnych polach oznaczają poziomy istotności. Wartości mniejsze niż 0,05 wskazują różnice nie mające charakteru przypadkowego. Wartości p pod tabelą odnoszą się do całej badanej próby.

Źródło: zob. przyp. 24.

Wprowadzone do modelu zmienne podzielić można na kulturowo-religijne (chrześcijanie-Żydzi) i społeczno-ekonomiczne (miejsce zamieszkania, zawód, alfabetyzacja). Jak się okazuje, ich siła oddziaływania na wysokość ciała i BMI była różna. W przypadku wysokości ciała najsilniej działało wyznanie, które miało nie tylko wymiar kulturowo-religijny, lecz również genetyczny. W warunkach stosunkowo rzadkiego krzyżowania się puli genowej obu badanych populacji w drodze małżeństw mieszanych należy przyjąć taką właśnie hipotezę. Tym samym zaobserwowaną różnicę wysokości ciała należy interpretować jako konsekwencję tyleż 
Tabela 6. Zależność wysokości ciała i BMI poborowych z guberni warszawskiej w 1913 roku od wyznania, miejsca zamieszkania, alfabetyzacji i zawodu

\begin{tabular}{|l|c|c|}
\hline \multicolumn{1}{|c|}{ Model } & Wysokość ciała & BMI \\
\hline Stała & $165,8^{*}$ & $21,87^{*}$ \\
\hline Wyznanie mojżeszowe & $-4,30^{*}$ & $-0,63^{*}$ \\
\hline Miejsce zamieszkania miasto & 0,15 & $-0,30^{*}$ \\
\hline Miejsce zamieszkania Warszawa & $0,71^{*}$ & $-0,75^{*}$ \\
\hline Znajomość pisma & $0,62^{*}$ & $-0,15^{*}$ \\
\hline Zawód handlowiec & $-0,09$ & 0,05 \\
\hline Zawód: robotnik niewykwalifikowany & $-0,35$ & $0,41^{*}$ \\
\hline Zawód rzemieślnik & $-0,61^{*}$ & 0,04 \\
\hline Zawód: prac. umysłowy & $1,66^{*}$ & $-0,12$ \\
\hline Zawód rolnik: & $-0,44$ & $0,68^{*}$ \\
\hline F & 96,911 & 118,184 \\
\hline $\mathrm{R}^{2}$ & 0,101 & 0,120 \\
\hline $\mathrm{N}$ & 7765 & 7765 \\
\hline
\end{tabular}

Stała: chrześcijanin, mieszkaniec wsi, analfabeta, bez zawodu.

Źródło: zob. przyp. 24.

różnych warunków bytowych, co i różnego potencjału genetycznego ${ }^{31}$. Spośród czynników społeczno-ekonomicznych podwyższających wysokość ciała wymienić należy zawód wymagający kwalifikacji, zamieszkanie w Warszawie oraz umiejętność czytania i pisania.

Całkiem inaczej przedstawiała się sytuacja w przypadku BMI. Choć różnica kulturowo-wyznaniowa i tutaj była statystycznie istotna i obniżała wartość indeksu o 0,63 punktu w przypadku Żydów, to znacznie silniej oddziaływały czynniki społeczno-ekonomiczne. Podniesieniu wartości BMI sprzyjało mieszkanie na wsi (por. wartość stałej), zatrudnienie $\mathrm{w}$ rolnictwie lub $\mathrm{w}$ charakterze robotnika niewykwalifikowanego. W tym ostatnim przypadku trzeba pamiętać, że - jak już wspomniano $-2 / 3$ poborowych określonych terminem czernoraboczij mieszkało

${ }^{31}$ We współczesnych badaniach polskich wysokości ciała poborowych podkreśla się, że cechą charakterystyczną populacji polskiej jest genetyczna jednolitość, której dowodzą podobne częstości występowania uwarunkowanych genetycznie, a nie środowiskowo czynników, takich jak grupa krwi czy kolor tęczówki oka. Natężenie tych cech jest zbliżone zarówno w różnych częściach współczesnej Polski, jak i w różnych grupach społecznych. Rzecz jasna, w Królestwie Polskim tak nie musiało być. 
na wsi. Bardzo silnie różnicujące okazało się też zamieszkiwanie w Warszawie, a także - ale w mniejszym stopniu - powiązana z miejscem zamieszkania znajomość pisma i wykonywanie zawodu wymagającego kwalifikacji.

\section{Próba interpretacji}

Jak wykazały badania dotyczące Wielkopolski, pod zaborem pruskim występowały prawidłowości podobne jak w Królestwie, choć kontrasty nie były tak wyraźne. Przeciętna wysokość ciała Żydów była niższa niż Polaków i Niemców o ponad $1 \mathrm{~cm}$ (wobec $4 \mathrm{~cm}$ w Królestwie), z kolei wskaźnik BMI dla Żydów był niemal identyczny jak dla Niemców i jednocześnie w istotny sposób niższy niż u Polaków (21,22 Żydzi, 21,15 Niemcy, Polacy 21,50$)^{32}$. Na stosunkowo wysokie BMI Polaków wpływał fakt, że znaczną część próby stanowili chłopi. Grażyna Liczbińska, Zbigniew Czapla, Oskar Nowak i Janusz Piontek przypisali tę odmienność różnicy w masie mięśniowej między mieszkańcami wsi i miast. Nie odnotowano za to w Wielkopolsce systematycznej różnicy w wysokości ciała pomiędzy miastami a wsią.

W przypadku Królestwa Polskiego powyższy schemat interpretacyjny sprawdza się tylko częściowo. Różnica wysokości ciała pomiędzy wsią a Warszawą (w przypadku chrześcijan) i pomiędzy małymi miastami a Warszawą (w przypadku Żydów) sugeruje zróżnicowanie standardu życia na korzyść wielkiego miasta. Zupełnie inaczej przedstawiają się wartości BMI. Trend ku ich zmniejszeniu w zależności od typu osiedla jest podobny jak w Wielkopolsce, tyle że znacznie silniej zarysowany. Odmienność polega na tym, że w Królestwie trend ten jest niezależny od struktury społecznej. W porównywalnych grupach zawodowych, takich jak robotnicy niewykwalifikowani chrześcijanie czy rzemieślnicy obu wyznań, różnica pomiędzy Warszawą a wsiami (chrześcijanie) lub Warszawą a małymi miasteczkami (Żydzi) jest znaczna i statystycznie istotna ${ }^{33}$. Trudno przypisywać robotnikom czy rzemieślnikom zamieszkującym Warszawę większą świadomość żywieniową, skoro książki kucharskie adresowane były do klasy średniej, a faktyczna dieta

${ }^{32}$ G. Liczbińska i in., op. cit.

${ }^{33}$ Chrześcijanie: rzemieślnicy $\mathrm{t}=6,171, \mathrm{p}=0,00$, robotnicy niewykwalifikowani $\mathrm{t}=5,072, \mathrm{p}=0,00$. Żydzi rzemieślnicy $\mathrm{t}=4,23, \mathrm{p}=0,00-\mathrm{t}$ jest wartością w rozkładzie $\mathrm{t}$ Studenta pozwalającą określić poziom istotności, czyli prawdopodobieństwo, że wniosek wyciągnięty na podstawie próby nie potwierdzi się w odniesieniu do całej populacji. W tym wypadku jest ono mniejsze niż 0,01 . 
robotników w miastach niewiele miała wspólnego z ich zaleceniami ${ }^{34}$. Przyczyny rozchodzenia się obu miar antropometrycznych muszą więc leżeć gdzie indziej.

Jak już wspomniano, stosując BMI w odniesieniu do populacji historycznych, mierzymy raczej masę mięśniową niż tłuszczową. Temu właśnie przypisać należy fakt, że ludność wsi miała wartość BMI wyższą niż ludność miast ${ }^{35}$. W miastach zaś najwyższe BMI - choć niższe niż na wsi - mieli robotnicy niewykwalifikowani wykonujący najcięższe prace fizyczne ${ }^{36}$. Fakt, że warszawiacy byli przeciętnie wyżsi od mieszkańców wsi (jest to prawidłowość niezależna od różnic struktury społecznej), świadczy, iż poziom życia w Warszawie był wyższy, w każdym razie dzieci tutaj urodzone dopóki pozostawały pod opieką rodziny, miały warunki wzrastania lepsze niż na wsi. Obniżenie BMI należy więc hipotetycznie powiązać z dwoma czynnikami - wspomnianą już mniejszą masą mięśniową mieszkańców miast oraz - być może - zmianą modelu konsumpcji żywności wśród młodych ludzi z chwilą wyjścia spod opieki rodzicielskiej, co następowało w momencie podjęcia pracy zawodowej. Miejsce konsumpcji żywności zajmowały inne pokusy życia miejskiego, od produktów kultury popularnej poczynając, a na papierosach i alkoholu kończąc ${ }^{37}$. To ostatnie wyjaśnienie musi pozostać hipotetyczne $\mathrm{z}$ uwagi na brak odpowiednich badań nad budżetami gospodarstw domowych, niemniej ma ono oparcie w pamiętnikach warszawskich robotników, którzy wspominali o niskim wynagrodzeniu w pierwszych latach pracy zawodowej, a więc w wieku zbliżonym do wieku poborowego ${ }^{38}$.

${ }^{34} \mathrm{O}$ zaleceniach dietetycznych i faktycznej konsumpcji żywnościowej na ziemiach polskich w XIX w., zob. E. Kaczyńska, „Zdrowe jedzenie” - zalecenia i polska rzeczywistość w XIX i XX wieku, RDSG 59, 1999, s. 127-154; W. Sobczak, Przełom w konsumpcji spożywczej w Królestwie Polskim w XIX wieku, Wrocław 1968.

35 Warto zauważyć, że u dziewiętnastoletnich poborowych polskich wartości BMI dla mieszkańców wsi w 1965 r. były większe niż dla miast liczących ponad 500 tys. mieszkańców. Potem trend ten się odwrócił, co świadczy o narastającym otłuszczeniu. O ile wartości średnie rosły nieznacznie, o tyle frakcja osób z nawagą we wszystkich przekrojach chronologicznych $(1965,1986,1995,2001)$ była w miastach wyraźnie większa niż na wsiach. T. Bielicki i in., Transformacja ustrojowa, s. 91, 94-97, tablice 21, 27-30.

36 BMI na wsi wynosiło 22,25, a w Warszawie 21,37 dla chrześcijan oraz 21,28 dla Żydów (Warszawa).

${ }^{37}$ Wedle Walentego Miklaszewskiego (Rozwój cielesny proletariatu Warszawy w świetle pomiarów antropometrycznych, Warszawa 1912, s. 98) inicjacja do palenia i picia alkoholu wśród proletariatu warszawskiego następowała bardzo wcześnie i ulegała przyspieszeniu w końcu XIX stulecia.

38 A. Żarnowska, Robotnicy Warszawy na przełomie XIX i XX wieku, Warszawa 1985, s. 169. 
Odpowiadając na sformułowane na początku tekstu pytania, należy skłonić się do opinii, że tym, co odróżniało Europę środkową od realiów angielskich i amerykańskich, była wyższa przeciętna wysokość ciała w dużych miastach, która dowodzi, że warunki życia miejskiego były korzystniejsze niż na wsi. W przypadku Warszawy z pewnością przyczyniły się do tego reformy sanitarne, przede wszystkim rozbudowa sieci wodociągowej i kanalizacyjnej, która współgrała ze spadkiem śmiertelności z 25 promili w latach osiemdziesiątych XIX w. do około 20 przed wybuchem I wojny światowej ${ }^{39}$. Obniżanie się BMI wraz z przejściem do dużego miasta było efektem zmiany stylu życia i wyborów konsumenckich zarówno wśród chrześcijan, jak i Żydów.

\section{Aneks}

\section{BMI - od poszukiwania człowieka przeciętnego do napiętnowania człowieka otyłego}

Iloraz wagi i wysokości ciała jako miarę pozwalającą ocenić budowę ciała zaproponował w $1823 \mathrm{r}$. belgijski statystyk Adolf Quetelet ${ }^{40}$. Celem jego badań było statystyczne zdefiniowanie „człowieka przeciętnego”. Metoda polegała na gromadzeniu danych o fizyczności, po to, by następnie wpisać je w rozkład normalny i poszukiwać nie ideału, lecz tendencji centralnej. Ponieważ masa ciała jest silnie skorelowana z wysokością, Quetelet poszukiwał formuły matematycznej uniezależniającej te wskaźniki. Obserwacja empiryczna skłoniła go do zaproponowania przytoczonej formuły, która zyskała miano indeksu Queteleta.

O ile celem Queteleta była systematyzacja obserwacji empirycznych, o tyle przedstawiciele biznesu ubezpieczeniowego z początku XX w. podchodzili do pomiarów ciała utylitarnie. W drugiej połowie XIX w. największe firmy sprzedające ubezpieczenia na życie rutynowo poprzedzały

39 O śmiertelności M. Nietyksza, Ludność Warszawy na przełomie XIX i XX wieku, Warszawa 1971, o reformach sanitarnych: A. Słoniowa, Poczatki nowoczesnej infrastruktury Warszawy, Warszawa, 1978; warto podkreślić, że konsumpcja wody bieżącej na głowę mieszkańca wzrosła w latach 1890-1913 z 30 do 83 litrów dziennie, A. Grotowski et al., Kanalizacja, wodociagi i pomiary miasta Warszawy, Warszawa 1911, s. 220-221.

${ }^{40}$ Quetelet posługiwał się ilorazem wagi ciała w gramach i wysokości ciała w centymetrach (wg współczesnej nomenklatury jest to wskaźnik Queteleta I). BMI (określany też jako wskaźnik Queteleta II) oblicza się jako iloraz wagi w kilogramach i kwadratu wysokości wyrażonego w metrach. G. Vigarello, op. cit, s. 231-237; G. Eknoyan, Adolphe Quetelet (1796-1874) - the Average Man and Indices of Obesity, „Nephrology, Dialysis, Transplantation” 23, 2008, s. 47-51; G. Sarton, Quetelet, „Isis” 23, 1935, s. 6-24. 
zawarcie kontraktu badaniem medycznym. Potencjalnych ubezpieczonych mierzono, ważono, pytano o przebyte choroby, stan zdrowia rodziców, niekiedy badano mocz, osłuchiwano, a z czasem mierzono również ciśnienie krwi. Ankietę uzupełniano charakterystykami społecznymi, takimi jak zawód, miejsce zamieszkania itp. ${ }^{41} \mathrm{~W}$ efekcie $\mathrm{w}$ archiwach największych firm ubezpieczeniowych nagromadziła się duża liczba oczekujących na opracowanie danych. Za ich systematyczną analizę wzięto się na przełomie XIX i XX stulecia, a celem było dostarczenie agentom ubezpieczeniowym racjonalnych przesłanek ułatwiających szacowanie ryzyka i wycenianie polis. Pierwszym studium tego rodzaju był wydany w 1903 r. raport zatytułowany Specialized Mortality Investigation, obejmujący dane osób ubezpieczonych w latach 1868-1900 przez 34 amerykańskie i kanadyjskie firmy ${ }^{42}$. Choć kilka lat później aktuariusze skrytykowali zastosowaną w raporcie metodologię, to nie kwestionowali samego modelu badania i leżącego u jego podstaw sposobu myślenia, odmiennego od modelu badawczego stosowanego w naukach medycznych.

Począwszy od przełomu spowodowanego odkryciami Louisa Pasteura i Roberta Kocha, medycyna stanęła na stanowisku monokauzalnego wyjaśniania przyczyn chorób. Analiza polegała na ustaleniu w postępowaniu laboratoryjnym ciągu przyczynowo-skutkowego właściwego dla danej jednostki chorobowej: znalezieniu drobnoustroju chorobotwórczego, opisaniu jego właściwości, opracowaniu remedium terapeutycznego i praktycznym jego zastosowaniu. Dopiero zrealizowanie wszystkich tych etapów badania pozwalało przyjąć, że jednostka chorobowa została rozpoznana i opanowana. Badania laboratoryjne prowadzono na niewielkiej liczbie przypadków, które dawały się następnie uogólnić na całą populację. W ten sposób opracowano skuteczne terapie i środki zapobiegawcze przeciw chorobom zakaźnym, co w konsekwencji doprowadziło do zmiany modelu umieralności. Metodologia ta okazała się zawodna w starciu z chorobami przewlekłymi, które stanowią współcześnie główną przyczynę zgonów. Sprawę utrudniał fakt, że etiologia tych schorzeń nie była znana, a często i dziś pozostaje zagadką.

$\mathrm{W}$ tej sytuacji sięgnięto $\mathrm{w}$ połowie XX w. po metodę probabilistyczną stosowaną przez aktuariuszy, której istotą jest wyodrębnienie czynników ryzyka sprzyjających powstaniu danego schorzenia, a co za tym idzie przyjęcie założenia o istnieniu więcej niż jednej przyczyny ${ }^{43}$. Bada-

${ }^{41}$ A.B. Davis, Life Insurance and the Physical Examination: A Chapter in the Rise of American Medical Technology, „Bulletin of the History of Medicine” 55, 1981, 3, s. 392-406.

${ }_{42}$ Actuarial Society of America, Specialized Mortality Investigation, New York 1903.

43 Obszernie na ten temat: W.G. Rothstein, Public Health and the Risk Factor. A History of an Uneven Medical Revolution, New York 2003. 
nie tego rodzaju prowadzi do porzucenia założenia o monokauzalności i przebadania bardzo dużych populacji, co z kolei wymusza posługiwanie się wskaźnikami łatwymi do obliczenia. Dopiero statystyczne potwierdzenie istnienia związku między czynnikiem ryzyka a śmiertelnością naprowadza na właściwą (lub z pozoru właściwą) ścieżkę, którą eksploruje się $\mathrm{w}$ drodze badań laboratoryjnych. Tak było w przypadku badań nad wpływem palenia tytoniu na rozwój chorób nowotworowych i roli cholesterolu w etiologii chorób krążenia ${ }^{44}$.

Jednym z odkryć autorów Specialized Mortality Investigation było dowiedzenie związku pomiędzy śmiertelnością a nieprawidłowym stosunkiem masy ciała do wysokości. Odkrycie to stanowiło przełom w postrzeganiu nadwagi. Choć już od dawna piętnowano otyłość w jej skrajnych przejawach, to nadmiar kilku czy kilkunastu kilogramów uznawano raczej za objaw dobrego zdrowia ${ }^{45}$. Tak w każdym razie nakazywało doświadczenie walki z gruźlicą. Jednak obserwacja z 1903 r. powtarzała się w każdym kolejnym badaniu. W 1937 r. wiceprezes Metropolitan Life Insurance Company, Louis Dublin, i matematyk ubezpieczeniowy Alfred Lotka opublikowali zestaw oszacowań normalnej masy dla osób o określonej wysokości ciała. Obliczenie trzech wariantów dla każdego poziomu wysokości uzasadniano koniecznością uwzględnienia różnych rodzajów budowy fizycznej. Ich średnią arytmetyczną traktowano jako masę preferowaną. Opierając się na danych o osobach ubezpieczonych w latach 1909-1928, obliczono, że prawdopodobieństwo zgonu mężczyzn w wieku 40-49 lat ważących o ponad $25 \% \mathrm{w}$ stosunku do normy wynosi 1,41 (przeciętna to 1,00 ), podczas gdy dla osób o wadze utrzymującej się w normie wynosi 0,86, a dla ważących o 5-14\% poniżej normy zaledwie $0,77^{46}$.

Przełom w dziejach badań nad nadwagą i otyłością jako czynnikiem ryzyka w chorobach chronicznych nastąpił po II wojnie światowej, kiedy świat medyczny i firmy ubezpieczeniowe zdały sobie sprawę, że na czoło wśród przyczyn zgonów osób dorosłych wysunęły się choroby krążenia, detronizując gruźlicę. W końcu lat czterdziestych zainicjowano szereg wieloletnich badań mających wytypować czynniki ryzyka chorób serca.

${ }^{44}$ O badaniach nad cholesterolem zob. M. Konarzewski, Na początku był głód, Warszawa 2005, s. 139-179.

${ }^{45}$ G. Eknoyan, A History of Obesity, or How What Was Good Became Ugly and Then Bad, „Advances in Chronic Kidney Disease" 13, 2006, 4, s. 424; J. Csergo, Food Consumption and Risk of Obesity: The Medical Discourse in France 1850-1950, w: The Rise of Obesity in Europe. A Twentieth Century Food History, red. D.J. Oddy, P.J. Atkins, V. Amilien, Farnham 2009.

${ }^{46}$ W.G. Rothstein, op. cit., s. 64; L.I. Dublin, A.J. Lotka, Twenty-Five Years of Health Progress: A Study of the Mortality Experience Among Industrial Policyholders of the Metropolitan Life Insurance Company 1911-1935, New York 1937. 
Do najważniejszych należały Framingham Heart Study, Minnesota Business and Professional Men's Study i nieco późniejszy Seven Countries Study, w którym porównano dane amerykańskie z doświadczeniem innych krajów. Wszystkie studia dowiodły związku między dietą i nadwagą - a ryzykiem zachorowań na choroby krążenia. Na formalne ogłoszenie otyłości jako jednego z najgroźniejszych czynników ryzyka w etiologii chorób chronicznych trzeba było jednak czekać do przełomu stuleci XX i XXI. Nie można wykluczyć, że nie doszłoby do tego, gdyby nie wprowadzenie do naukowego obiegu jednolitej miary otyłości, czyli wskaźnika Queteleta.

Swój renesans zawdzięcza on Ancelowi Keysowi, amerykańskiemu fizjologowi, który zyskał międzynarodową renomę jako inicjator badań nad zachorowalnością na choroby serca wśród przedsiębiorców z Minnesoty i Seven Countries Study. W 1972 r. na łamach czasopisma "Journal of Chronic Diseases" opublikował on artykuł, w którym zestawił stosowane dotąd miary otyłości. Z wyliczeń wynikało, że najłatwiejszy do obliczenia i jednocześnie najlepiej reagujący na zmiany masy przy stałej wysokości ciała jest wskaźnik Queteleta II, który Keys ochrzcił mianem indeksu masy ciała (Body Mass Index, BMI) ${ }^{47}$. W 1979 r. inny amerykański fizjolog, George Bray, zaproponował powszechnie dziś stosowaną interpretację wartości BMI, zgodnie z którą wynik powyżej 25 dla mężczyzn (dla kobiet 23,5) oznacza nadwagę, a powyżej 30 - otyłość ${ }^{48}$. Przyjęcie standardowego wskaźnika i ostrych wartości granicznych przyczyniło się do upowszechnienia BMI jako uniwersalnej miary otłuszczenia. I jak to bywa $\mathrm{z}$ wieloma standardami - choćby PKB - jego wprowadzenie zatarło w świadomości wielu użytkowników wieloznaczności interpretacyjne kryjące się w pozornie jednoznacznych liczbach.

\section{Streszczenie}

Wysokość i wskaźnik masy ciała są miarami antropologicznymi coraz częściej wykorzystywanymi w dociekaniach nad standardem życia populacji historycznych. Przedmiotem artykułu jest ocena, w jaki sposób w miarach tych odzwierciedlają różnice wyznaniowe (chrześcijanie-Żydzi) oraz społeczno-ekonomiczne (miejsca

${ }^{47}$ A. Keys i in., Indices of Relative Weight and Adiposity, "Journal of Chronic Diseases” 25, 1972, s. 329-343.

${ }^{48}$ G.A. Bray, Overview, w: Obesity in America, Bethesda 1979, s. 6; zob. też I. Fletcher, „Obesity: a Historical Account of the Construction of a Modern Epidemic", Glasgow 2012 (praca doktorska), s. 145-172, www.era.lib.ed.ac.uk/bitstream/handle/1842/6453/ Fletscher2012.pdf?sequence=1\&isAllowed=y (dostęp: 16 VIII 2016). 
zamieszkania, zawód, stopień alfabetyzacji) dzielące mieszkańców Królestwa Polskiego u progu Wielkiej Wojny. Podstawę źródłową stanowi blisko 8 tys. pomiarów dwudziestojednoletnich poborowych z guberni warszawskiej.

Wysokość ciała i BMI (Body Mass Index) w przekroju chrześcijanie - Żydzi różniły się w sposób statystycznie istotny na niekorzyść tych ostatnich. Nie mniej istotny wpływ na różnice miało miejsce zamieszkania. O ile pod względem wysokości ciała zamieszkali w Warszawie górowali nad mieszkańcami wsi i małych miast, o tyle ich BMI było niższe; aż 20\% poborowych ze środowiska Żydów warszawskich cechowała niedowaga.

Zróżnicowanie wysokości ciała dowodzi, że w miastach standard życia był wyższy niż na wsi i w małych miastach. Niższe wartości BMI w Warszawie wyjaśnić można dwiema przyczynami. Po pierwsze, BMI w dawnych populacjach mierzy nie tyle otłuszczenie ciała, co masę mięśniową, która była wyższa na wsi. Po wtóre, dysproporcja między wysokością ciała a BMI w Warszawie odzwierciedla zmianę udziału wydatków na żywność w budżetach. Prawdopodobnie, z chwilą usamodzielnienia się młodzi mężczyźni ograniczali konsumpcję żywności, przeznaczając więcej środków na inne towary i rozrywki możliwe do nabycia w wielkim mieście.

\section{The Human Body and the Town: Recruits in the Gubernia of Warsaw in 1913}

Height and Body Mass Index are anthropological measurements increasingly often used in studies on the standard of living of historical populations. This article conducts an assessment of the way in which those measurements reflect religious (Christians-Jews) and socio-economic (place of residence, profession, literacy) differences dividing the inhabitants of the Kingdom of Poland upon the eve of the Great War. The basic sources are almost 8000 measurements of 21-year old recruits from the gubernia of Warsaw.

Height and BMI (Body Mass Index) in the Christians-Jews cross-section statistically differed to the disadvantage of the latter group. An equally essential impact was exerted by the place of residence. The residents of Warsaw were taller than the inhabitants of villages and small towns, but their BMI was lower; as many as $20 \%$ of Jewish recruits from Warsaw were underweight.

The differentiation of height proves that the standard of living in towns was higher than in the countryside and small towns. In the case of Warsaw lower BMI could be explained by two causes: first, in past populations BMI measured not so much body fat as the muscle mass, which was higher in the villages. Second, the disproportion between height and BMI in Warsaw reflected a change in the participation of food expenses in household budgets. The moment young men became independent they probably limited food consumption and spent more on other commodities and entertainment available in large cities.

Translated by Aleksandra Rodzińska-Chojnowska 


\section{Bibliografia}

Bielicki, Tadeusz, Alicja Szklarska, Sławomir Kozieł, Zygmunt Welon. Transformacja ustrojowa $w$ Polsce $w$ świetle antropologicznych badań 19-letnich poborowych. Wrocław: Zakład Antropologii PAN, 2003.

Bielicki, Tadeusz, Alicja Szklarska, Zygmunt Welon, Czesław Brajczewski. Nierówności społeczne w Polsce: antropologiczne badania poborowych $w$ trzydziestoleciu 1965-1995. Wrocław: Zakład Antropologii PAN, 1997.

Bogin, Bary, Inez Varela-Silva, „The Body Mass Index: the Good, the Bad, and the Horrid". Bulletin der Schweizerischen Gesellschaft für Anthropologie 18, nr 2 (2012): $5-11$.

Carson, Scott A. „The Body Mass Index of Blacks and Whites in the United States during the Nineteenth Century". The Journal of Interdisciplinary History 42, nr 3 (2012): 371-391.

Coclanis, Peter A., John Komlos. „Nutrition and Economic Development in Post-Reconstruction South Carolina: An Anthropometric Approach". Social Science History 19, nr 1 (1995): 91-115.

Floud, Roderick, Robert W. Fogel, Bernard Harris, Sok Chul Hong. The Changing Body: Health, Nutrition, and Human Development in the Western World since 1700. New York: Cambridge University Press, 2011.

Fogel, Robert W. The Escape from Hunger and Premature Death, 1700-2100. Europe, America, and the Third World. New York: Cambridge University Press, 2004.

Fogel, Robert W., Dora L. Costa. „A Theory of Technophysioevolution, With Some Implications for Forecasting Population, Health Care Costs, and Pension Costs". Demography 34 (1977): 49-66.

Huck, Paul. „Infant mortality and the standard of living during the British industrial revolution". The Journal of Economic History 53, nr 2 (1993): 399-401.

Kaczyńska, Elżbieta. „Zdrowe jedzenie - zalecenia i polska rzeczywistość w XIX i XX wieku”. Roczniki Dziejów Społecznych i Gospodarczych 59 (1999): 127-154.

Komlos, John. „The Height Increment and BMI Values of Elite Central European Children and Youth in the Second Half of the 19th Century". Annals of Human Biology 33, nr 3 (2006): 309-318.

Komlos, John. „Shrinking in a Growing Economy? The Mystery of Physical Stature during the Industrial Revolution". The Journal of Economic History 58, nr 3 (1998): 779-802.

Komlos, John. „A Three-Decade History of the Antebellum Puzzle: Explaining the Shrinking of the U.S. Population at the Onset of Modern Economic Growth". The Journal of the Historical Society 12, nr 4 (2012): 395-445.

Komlos, John, Marek Brabec. „The Trend of BMI Values of US Adults by Deciles, Birth Cohorts 1882-1986 Stratified by Gender and Ethnicity". Economics and Human Biology 9, nr 3 (2011): 234-250.

Kopczyński, Michał. „Pobór do armii rosyjskiej w Warszawie i guberni warszawskiej, 1874-1913". Rocznik Warszawski 35 (2007): 87-109.

Kopczyński, Michał. Wielka transformacja. Badania nad uwarstwieniem społecznym $i$ standardem życia w Królestwie Polskim 1866-1913 w świetle pomiarów antropometrycznych poborowych. Warszawa: Oficyna Wydawnicza „Mówią Wieki”, 2006. 
Kuklo, Cezary, Juliusz Łukasiewicz, Cecylia Leszczyńska. Historia Polski w liczbach. Polska w Europie. Warszawa: Główny Urząd Statystyczny, 2014.

Kułaga, Zbigniew, Agnieszka Różdżyńska, Iwona Palczewska, Aneta Grajda, Beata Gurzkowska, Ewelina Napieralska, Mieczysław Litwin, et alia. „Siatki centylowe wysokości, masy ciała i wskaźnika masy ciała dzieci i młodzieży w Polsce wyniki badania OLAF". Standardy Medyczne. Pediatria 7 (2010): 690-700.

Lasker, Gabriel Ward, C.G. Nicholas Mascie-Taylor, „Effects of Social Class Differences and Social Mobility on Growth in Height, Weight and Body Mass Index in a British Cohort". Annals of Human Biology 16, nr 1 (1989): 1-8.

Liczbińska, Grażyna. Umieralność i jej uwarunkowania wśród katolickiej i ewangelickiej ludności historycznego Poznania. Poznań: Biblioteka Telgte, 2009.

Liczbińska, Grażyna, Zbigniew Czapla, Oskar Nowak, Janusz Piontek. „Body Mass Index Values of Conscripts in the Polish Lands under Prussian Rule in the Late 19th and Early 20th Centuries". Economics and Human Biology 21 (2016): 75-83.

Nietyksza, Maria. Ludność Warszawy na przełomie XIX i XX wieku. Warszawa: Państwowe Wydawnictwo Naukowe, 1971.

Nowak, Oskar. Wysokość ciała i masa ciała młodych mężczyzn w okresie przemian historycznych i społeczno-gospodarczych drugiej połowy XIX i na początku XX wieku na ziemiach polskich. Poznań: Wydawnictwo Naukowe Uniwersytetu im. Adama Mickiewicza w Poznaniu, 2011.

Steckel, Richard H. „Heights and Human Welfare: Recent Developments and New Directions". Explorations in Economic History 46, nr 1 (2009): 1-23.

Steckel, Richard H., Roderick Floud, red. Height and Welfare during Industrialization. New York: National Bureau of Economic Research, 1997.

Żarnowska, Anna. Robotnicy Warszawy na przełomie XIX i XX wieku. Warszawa: Państwowy Instytut Wydawniczy, 1985.

Biogramy: Michał Kopczyński - dr hab. prof. UW, Instytut Historyczny UW. Zajmuje się antropometrią historyczną i demografią historyczną. Kontakt: m.kopczynski@uw.edu.pl.

Łukasz Mirosław Sobechowicz - doktorant na Wydziale Historycznym UW. Członek Zespołu Wystawy Stałej w Muzeum Historii Polski. Zainteresowania badawcze skupiają się wokół historii gospodarczej i demografii, ze szczególnym uwzględnieniem problemu kohabitacji ludzi i zwierząt w środowisku miejskim. Kontakt: lukasz.sobechowicz@gmail.com. 